TITLE:

\title{
CONTRIBUTIONS TO JAPANESE ASCIDIAN FAUNA. VI -SIMPLE ASCIDIANS OF THE MUSEUM OF HUKUI-
}

AUTHOR(S):

Tokioka, Takasi

\section{CITATION:}

Tokioka, Takasi. CONTRIBUTIONS TO JAPANESE ASCIDIAN FAUNA. VI -SIMPLE ASCIDIANS OF THE MUSEUM OF HUKUI-. PUBLICATIONS OF THE SETO MARINE BIOLOGICAL LABORATORY 1953, 3(1): 27-32

ISSUE DATE:

1953-07-30

URL:

http://hdl.handle.net/2433/174463

RIGHT: 


\title{
CONTRIBUTIONS TO JAPANESE ASCIDIAN FAUNA. VI SIMPLE ASCIDIANS OF THE MUSEUM OF HUKUI ${ }^{12}$
}

\author{
TAKASI TOKIOKA
}

Seto Marine Biological Laboratory, Sirahama

With Plate $I$ and 3 Text-figures

A small collection of simple ascidians of the local museum of Hukui, the chief city of Hukui-Prefecture on the Japan Sea side, was offered to me for examination. All these specimens were collected by Mr. Sadahitr Hobayashi of Haruyama Primary School of the city. They are:-

*1 Cnemidocarpa macrogastra (OKA)

2 Styela plicata (Lesueur)-Loc.: Obama Bay.

*3 Styela longipedata ToKroka

*4 Pyura lepidoderma Tokioka

*5 Herdmania momus (Savigny)

6 Haloc ynthia roretzi (DRASCHE) - Loc.: Turuga Bay.

7 Podocynthia turboja OKa-Loc.: Obama Bay.

8 Microcosmus multitentaculatus Tokroka-Loc.: Obama Bay.

Four species with an asterisk were found attached to a single shell of Turcica coreensis PEAsE, dredged in Obama Bay and $38 \mathrm{~mm}$ in height. I wish to give some notes on some of these specimens in the following.

Cnemidocarpa macrogastra (OKA), 1935

(Plate I, Fig. 1; Text-fig. 1)

A $25 \mathrm{~mm}$ long $\times 17 \mathrm{~mm}$ high, oval individual. Apertures are situated on the dorsal side and about $10 \mathrm{~mm}$ apart from each other, they are sessile and 4-lobed. Test ca. $0.5 \mathrm{~mm}$ in thickness, very tough and whitish in colour. Surface nearly. smooth. Many endocarps on the inner side of the mantle. Atrial tentacles numerous.

1) Contributions from the Seto Marine Biological Laboratory, No. 199.

Publ. Seto Mar. Biol. Lab., III (1), 1953. (Article 2) 
Branchial sac: Inner longitudinal vessels on folds much more numerous than in specimens previously recorded. Intermediate vessels numerous as in specimens reported from Sagami Bay.
Left
D. 1
(31) 7
(27) 6
(26) 6
(18) $5 \mathrm{~V}$.
Right
D. 3
30) 8
(33) 5
(27) 7
(21) $4 \mathrm{~V}$.
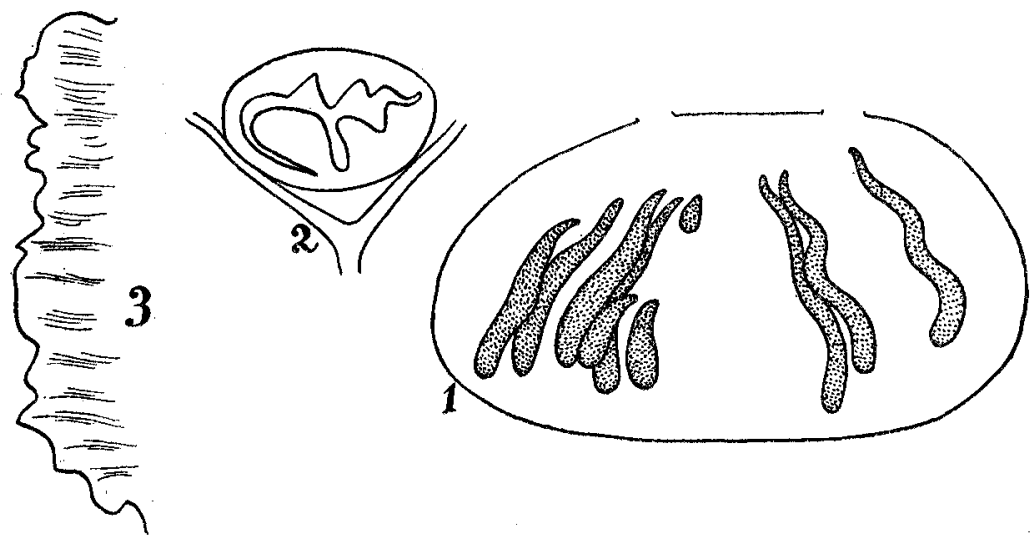

Fig.1. Cnemidocarpa macrogastra (ОкА). 1-Right half of mantle body from inside, 2--Dorsal tubercle, enlarged; 3-Serrated part of dorsal lamina, $\times 45$.

Three to seven thin transverse vessels between a pair of thicker ones. Parastigmatic vessels present. Three to five stigmata in a mesh. About 25 tentacles including large and small ones. Ciliated groove shows a rather irregular course. Dorsal lamina very broad, partially serrated as shown in Text-fig. 1-3.

Alimentary system: Stomach occupies more than a half of the ventral branch of the intestinal loop. Anus with ca. 10 faint lobes.

Gonad: Ten on the right side and nine on the left.

Styela longipedata TokIoKA, 1953

A $70 \mathrm{~mm}$ long individual, a half of the body length occupied by body proper. Stalk thin. Siphons strongly contracted. Ciliated groove U-shaped.

Pyura lepidoderma ToKIOKA, 1949

(Plate I, Fig. 2)

A $10 \mathrm{~mm}$ long $\times 10 \mathrm{~mm}$ high indjvidual. The test whitish in colour. 
Herdmania momus (SAVIGNY), 1816

One specimen, $18 \mathrm{~mm} \times 21 \mathrm{~mm}$ in size, whitish in colotrr and rather in bad state of preservation.

\section{Podocynthia turboja OKA, 1929}

(Plate I, Fig. 3 ; Text-fig. 2)

OKA, A. (1929): Ueber eine neue gestielte Monascidie Podocynthia turboja n.g. sp., Proc. Imp. Acad., Vol. V, No. 2, pp. 94-96, Figs. A \& B.

One specimen in the material. Body globular, $15 \mathrm{~mm}$ long $\times 12 \mathrm{~mm}$ wide and with apertures on small prominences situated at the anterior side of the body; stalk $38 \mathrm{~mm}$ in length, ca. $2 \mathrm{~mm}$ in thickness near the anterior end and ca. $1 \mathrm{~mm}$ near the posterior end which is ramified and holds gravels between the branches. Small root-like side prominences are issued from the stalk. The animal seems to be laying on the substratum.
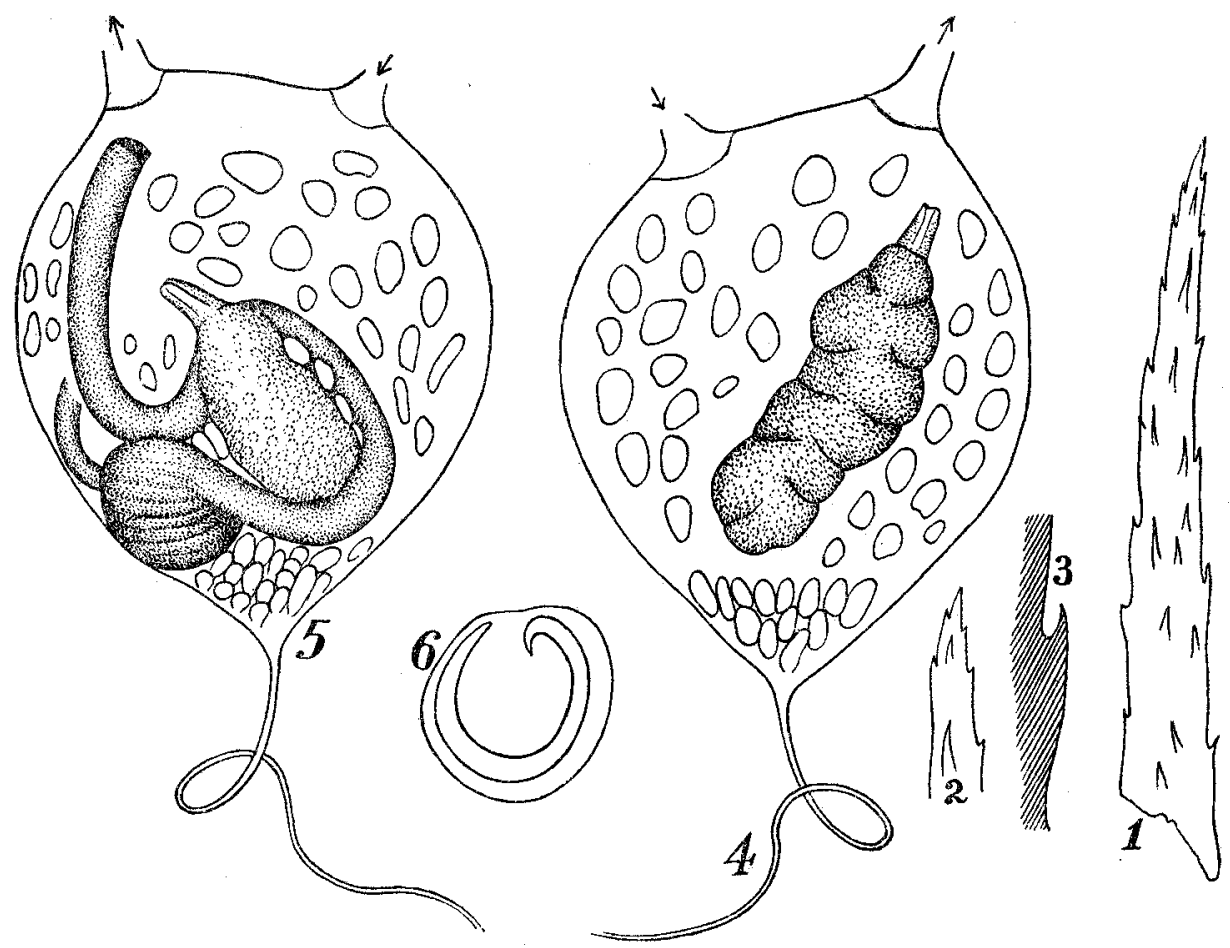

Fig. 2. Podocynthia turboja ОКА. 1 -Large spine around atrial aperture, $\times 75$; 2-Small spine, $\times 75 ; 3-$ Spinule, $\times 200 ; 4$--Right half of mantle body from inside, 5 -Left half of mantle body from inside, 6-Dorsal tubercle, enlarged. 
Test very thin, but tough. It is whitish on the body proper and pale yellowish on the stalk. The whole surface is covered with minute spines; spines on the stalk are sparsely distributed and slightly longer than those on the body proper. Several large spines found around the atrial aperture. Spines are all armed with spinules.

Spines on the body proper ................... about $280 \mu$ in length.

Spines on the stalk about $350 \mu$ in length

Large spines around the atrial aperture about $1.2 \mathrm{~mm}$ in length.

Mantle very thin and translucent. A thin vascular prominence issued from the posterior end of the body and penetrates the stalk. Atrial velum well developed. Many endocarps on the inner side.

Branchial sac: Seven folds on the left side and eight on the right. Arrangement of the inner longitudinal vessels can not be examined in detail, because the branchial sac is considerably mutilated. Probably, about a dozen vessels on each fold and 1-2 vessels in the interspace. Parastigmatic vessels found in many places. Five to six stigmata in a mesh. Tentacles ca. 15 including large and small ones; branches in 2 orders. Ciliated groove U-shaped. Dorsal lamina represented by a series of languets as in Pyura, Herdmania and Halocynthia.

Alimentary system: First intestinal loop nearly circtlar, second loop wide and distinct. Rectum long, anus plainly margined. Stomach globular, longitudinally plicated except for the dorsal side. Follicular hepatic lobes absent.

Gonad: One massive and orange brown gonad on each side.

Remarks: OKA's original description on the dorsal lamina ... "Dorsalfalte: ziemlich breit, dünn, gerippt, mit dünnen, langen, den Rippen entsprechenden Zähnen "... differs considerably from the description on the present specimen, in which the lamina is represented by a series of languets arranged on the crest. This difference is easily attributable to the difference in the state of contraction. The most incomprehensive difference is that found in the gastric region of the alimentary system. The original description is ... "Magen nicht deutlich abgesetzt, mit zahlreichen kleinen Leberanhängen". I consider, however, that the following idea is not impossible that the gastric region has longitudinal plications, besides small follicular hepatic lobes which may be missing in some individuals or easily torn off in the course of dissection. The distinctness of the gastric region may occur as a restlt of the contraction of the body. If this idea is allowed, differences between the genera Podocynthia and Halocynthia must be reduced to the single point that Podocynthia has the dorsal lamina, somewhat broad and with deeply serrated margin, while Halocynthia has a series of languets 
in place of a membrance. The existence of the stalk and the fewness of gonads can not be considered to be of generic importance. As to the fewness of gonads, we may cite Halocynthia igaguri TокIоKA as an example. Lastly, it must be further discussed whether the difference in the appearance of the dorsal lamina, mentioned above, is worthy to be treated as a characteristic of the generic importance or not.

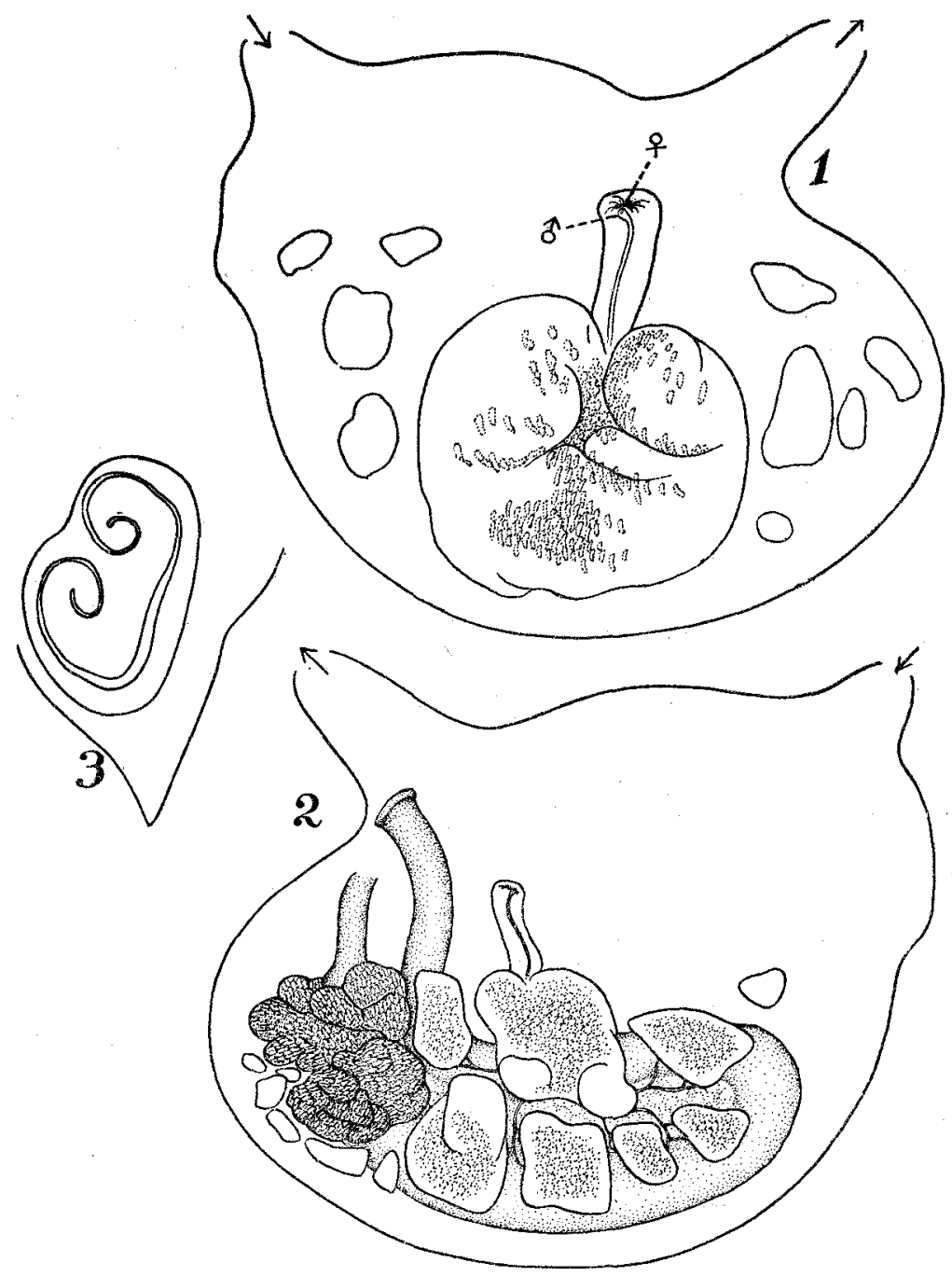

Fig. 3. Microcosmus multitentaculatus 'ГОКІОКА. 1-Right half of mantle body from inside, 2-Left half of mantle body from inside, 3-Dorsal tubercle, enlarged. 


\title{
Microcosmus multitentaculatus 'ToKIOKA, 1953
}

\author{
(Plate I, Fig. 4 ; Text-fig. 3)
}

One specimen in the material; $42 \mathrm{~mm}$ in length, $32 \mathrm{~mm}$ in breadth and $45 \mathrm{~mm}$ in height. The animal attached to the substratum by the ventral side which issues many root-like protuberances holding gravels or carrying sand grains and reaches $22 \mathrm{~mm}$ in height. Branchial aperture subterminal, atrial aperture slightly behind the middle of the body. Both siphons very short, but stout; apertures 4-lobed. The dorsal side of the body is strongly corrugated. Test yellowish and sprinkled with red patches at several parts. It is ca. $1 \mathrm{~mm}$ in thickness, leathery, hard and very tough; inner surface white and glistening. Mantle body ca. $30 \mathrm{~mm}$ in height. Mantle of moderate thickness and yellowish brown in colour. Atrial velum well developed. Several endocarps on the inner side.

Branchial sac: Inner longitudinal vessels arranged as follows:

Left $\quad$ D. 2 (26) 1 (24) 1 (26) 1 (25) 2 (23) 3 (20) 1 (13) 1 V.

Right D. 1 (27) 1 (26) 1 (26) 1 (26) 2 (24) 2 (22) 2 (18) 0 V.

Transverse vessels arranged as...thick-thin-thin-thin-medium-thin-thin-thinthick... . Parastigmatic vessels present. Eight to ten small stigmata in a mesh. Tentacles 24, including large and small ones: branches in 3 orders. Ciliated groove $\mathrm{U}$-shaped, with incurled anterior horns.

Alimentary system: Anus plainly margined.

Gonad: One gonad on each side. The right gonad is roundish in outline, while the left gonad consists of 7 capsules arranged roughly in two transverse rows on the narrow intestinal loop. Ovary developes merely in the middle capsule of the dorsal row indicated by a distinct gonoduct, other 6 capsules contain only testicular follicles and issue each thin vasa efferentia toward the capsule containing ovary.

\section{EXPLANATION OF PLATE I}

1. Cnemidocarpa macrogastra (OKA), dorsal side.

2. P yura lepidoderma ToкIокA, right side.

3. Podocynthia turboja OKA, right side.

4. Microcosmus multitentaculatus TокIокA, right side. 
Publ. Seto Mar. Biol. Lab., III, 1 (1953) PLATE I.
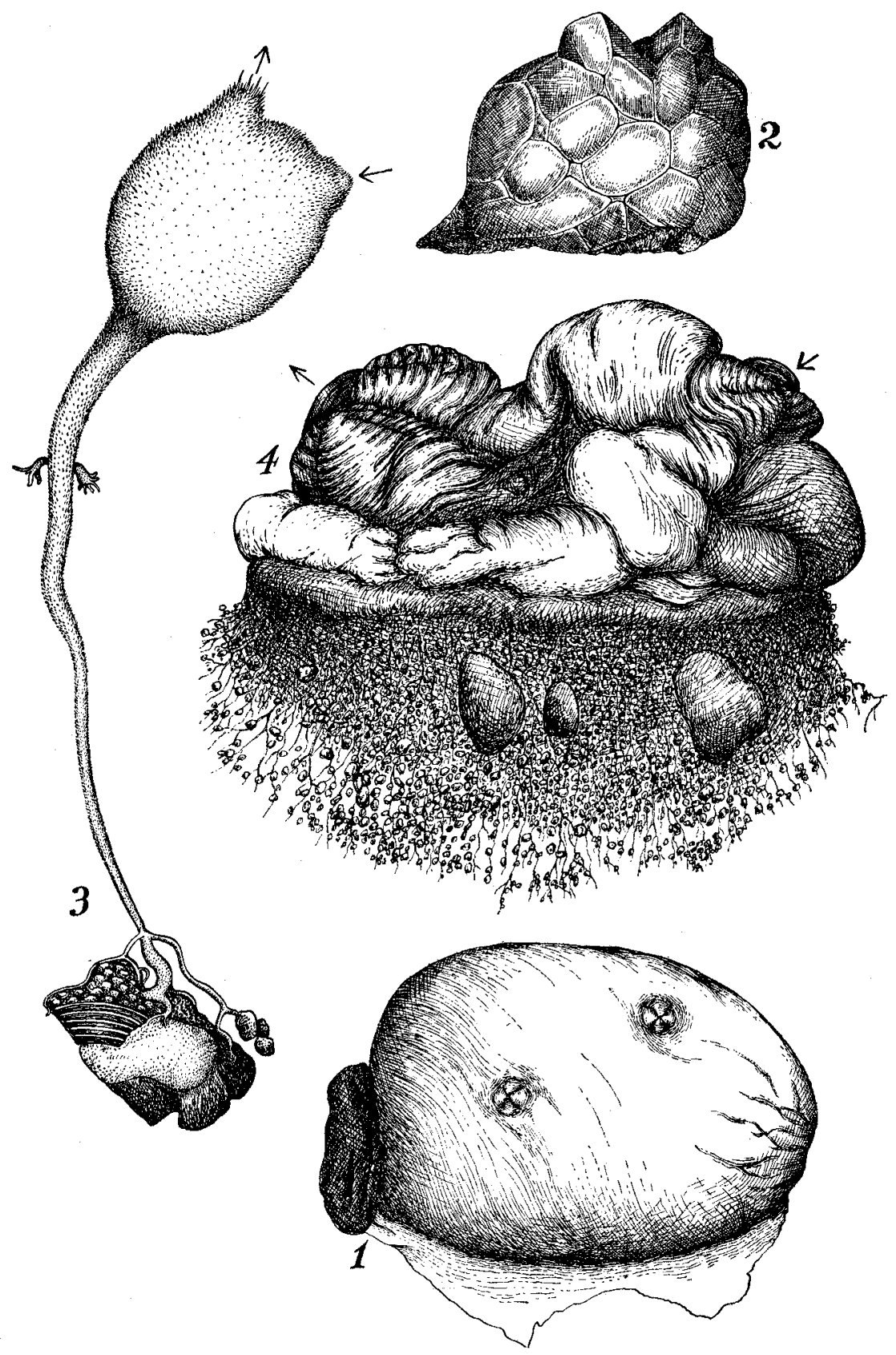

T. TOKIOKa: Contributions to Japanese Ascidian Fauna, Vi, 